\title{
2-(2-Phenylethyl)chromone Derivatives of Agarwood Originating from Gyrinops salicifolia
}

\author{
Hang Shao ${ }^{1,2}$, Wen-Li Mei ${ }^{2}$, Wen-Hua Dong ${ }^{2}$, Cui-Juan Gai ${ }^{2}$, Wei Li ${ }^{2}$, Guo-Peng Zhu ${ }^{1, *}$ \\ and Hao-Fu Dai ${ }^{2, *}$ \\ 1 Horticultural and Garden College, Hainan University, Haikou 570228, Hainan, China; \\ shaohang126@163.com \\ 2 Key Laboratory of Biology and Genetic Resources of Tropical Crops, Ministry of Agriculture, \\ Institute of Tropical Bioscience and Biotechnology, Chinese Academy of Tropical Agricultural Sciences, \\ Haikou 571101, Hainan, China; meiwenli@itbb.org.cn (W.-L.M.); dongwenhua@itbb.org.cn (W.-H.D.); \\ gaicuijuan@163.com (C.-J.G.); liwei@itbb.org.cn (W.L.) \\ * Correspondence: guopengzhu@163.com (G.-P.Z.); daihaofu@itbb.org.cn (H.-F.D.); \\ Tel./Fax: +86-898-66291220 (G.-P.Z.); +86-898-66961869 (H.-F.D.)
}

Academic Editor: Derek J. McPhee

Received: 1 September 2016; Accepted: 26 September 2016; Published: 3 October 2016

\begin{abstract}
Three new 2-(2-phenylethyl)chromone derivatives (1-3) and a new 2-(2-phenylethenyl)chromone derivative (4), together with two known 2-(2-phenylethyl)chromone derivatives (5-6), were isolated from agarwood originating from Gyrinops salicifolia Ridl. The structures of compounds 1-4 were elucidated by comprehensive spectroscopic techniques (UV, IR, 1D and 2D-NMR) and MS analysis, as well as by comparison with the literature. Compounds $\mathbf{1}, \mathbf{2}$, and $\mathbf{5}$ showed moderate cytotoxicity against human tumor K562, BEL-7402, and SGC-7901 cell lines with $\mathrm{IC}_{50}$ values of 5.76 to $20.1 \mu \mathrm{M}$.
\end{abstract}

Keywords: 2-(2-phenylethyl)chromone derivative; 2-(2-phenylethenyl)chromone derivative; agarwood; Gyrinops salicifolia; cytotoxicity

\section{Introduction}

Agarwood (Chen-Xiang in Chinese) is the resinous heartwood of the plants from the Aquilaria or Gyrinops genus that belong to the family of Thymelaeaceae [1]. It is well known as a traditional medicinal and natural perfume material, and has become more and more prevalent in international trade [2,3]. As traditional medicine, agarwood can alleviate stomachaches and ease symptoms of cough, rheumatism and high fever. Furthermore, its special fragrance is able to calm people down and relieve fatigue [4,5]. Agarwood formation occurs slowly and infrequently in nature and the supply of wild agarwood cannot meet the market demand, so the studies on fragrant constituents and related biosynthetic genes [5-9], as well as the search for wild agarwood-producing species [10], become critical.

Gyrinops salicifolia, currently listed in CITES Appendix II [11], is one of the agarwood-producing endemic species in Papua New Guinea. Previous studies on agarwood mainly focused on the resins obtained from Aquilaria species [5,6], although Gyrinops species also produce agarwood. As far as we know, the only report on chemical constituents of Gyrinops species is on the leaves and stems of Gyrinops walla [12]. It is worth noting that the chemical constituents of resins from Gyrinops walla identified by GC-MS were chemically similar to those from Aquilaria sp. [13]. So far, it has been reported that 2-(2-phenylethyl)chromone derivatives and sesquiterpenes were the main chemical constituents of agarwood $[5,6,14,15]$. Our study on chemical constituents of the agarwood from Gyrinops salicifolia led to isolation of three new 2-(2-phenylethyl)chromone derivatives (1-3) and a new 2-(2-phenylethenyl)chromone derivative (4), together with two known chromone derivatives $(5,6)$ 
(Figure 1). In this paper, the isolation and structure elucidation of compounds 1-6 as well as cytotoxic activity against human tumor K562, BEL-7402, SGC-7901 cell lines is described.

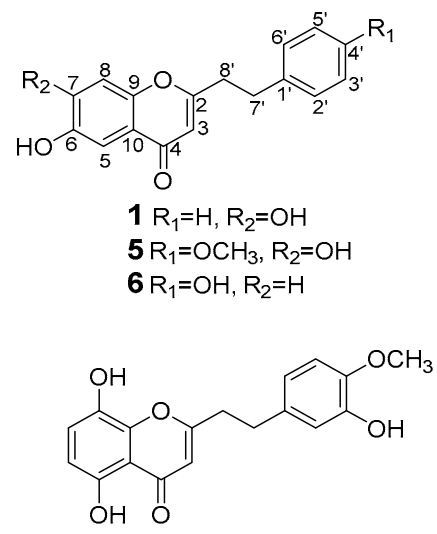

3<smiles>COc1ccc(CCc2cc(=O)c3cc(O)c(OC)cc3o2)cc1</smiles><smiles>COc1ccc(/C=C/c2cc(=O)c3c(O)cccc3o2)cc1</smiles>

Figure 1. Chemical structure of compounds 1-6.

\section{Results and Discussion}

Compound 1 was obtained as a jacinth powder. Its molecular formula was deduced to be $\mathrm{C}_{17} \mathrm{H}_{14} \mathrm{O}_{4}$ on the basis of HR-ESI-MS $\left(m / z 281.0820[\mathrm{M}-\mathrm{H}]^{-}\right)$. The IR spectrum revealed the presence of hydroxyl $\left(3434 \mathrm{~cm}^{-1}\right)$ and $\alpha, \beta$-unsaturated carbonyl $\left(1632 \mathrm{~cm}^{-1}\right)$ functionalities. The ${ }^{1} \mathrm{H}-\mathrm{NMR}$ (Table 1, Supplementary) spectrum displayed two hydroxyl proton resonances at $\delta_{\mathrm{H}} 10.35(1 \mathrm{H}, \mathrm{s}, 7-\mathrm{OH})$ and $9.70(1 \mathrm{H}, \mathrm{s}, 6-\mathrm{OH})$, two para-position aromatic protons at $\delta_{\mathrm{H}} 7.22(1 \mathrm{H}, \mathrm{s}, \mathrm{H}-5)$ and $6.84(1 \mathrm{H}, \mathrm{s}, \mathrm{H}-8)$, five characteristic protons on the mono-substituted aromatic ring at $\delta_{\mathrm{H}} 7.26\left(4 \mathrm{H}, \mathrm{m}, \mathrm{H}-2^{\prime}, 3^{\prime}, 5^{\prime}, 6^{\prime}\right)$ and $\delta_{\mathrm{H}} 7.19\left(1 \mathrm{H}, \mathrm{m}, \mathrm{H}-4^{\prime}\right)$, one olefinic proton at $\delta_{\mathrm{H}} 5.99(1 \mathrm{H}, \mathrm{s}, \mathrm{H}-3)$, as well as four methylene protons at $\delta_{\mathrm{H}} 2.97\left(2 \mathrm{H}, \mathrm{m}, \mathrm{H}_{2}-7^{\prime}\right)$ and $\delta_{\mathrm{H}} 2.90\left(2 \mathrm{H}, \mathrm{m}, \mathrm{H}_{2}-8^{\prime}\right)$ which connected to each other according to the ${ }^{1} \mathrm{H}_{-}{ }^{1} \mathrm{H}$ COSY correlation from $\mathrm{H}_{2}-7^{\prime}$ to $\mathrm{H}_{2}-8^{\prime}$ (Figure 2). The ${ }^{13} \mathrm{C}-\mathrm{NMR}$ (Table 1 ) and HSQC spectra showed that compound 1 contained a chromone nucleus by the signals at $\delta_{C} 107.6$ (C-5), 144.3 (C-6), 152.0 (C-7), 102.8 (C-8), 115.8 (C-10) and 151.0 (C-9), as well as an $\alpha, \beta$-unsaturated carbonyl moiety by signals at $\delta_{\mathrm{C}} 167.2(\mathrm{C}-2), 108.6(\mathrm{C}-3)$ and 176.0 (C-4). Additional signals included a mono-substituted aromatic ring $\left(C-1^{\prime}\left(\delta_{C} 140.2\right), C-2^{\prime} / 6^{\prime}\left(\delta_{C} 128.4\right), C-3^{\prime} / 5^{\prime}\left(\delta_{C} 128.3\right), C-4^{\prime}\left(\delta_{C} 126.2\right)\right)$ and two methylene carbons at $\delta_{C} 32.1\left(C-7^{\prime}\right)$ and $34.7\left(C-8^{\prime}\right)$. These data were quite similar to those of compound 5 [16], with the main difference observed being the replacement of signals for the 4-methoxyphenyl unit in 5 by signals for the phenyl unit in $\mathbf{1}$. It can be further confirmed by the observed HMBC correlation from H-5 $\left(\delta_{\mathrm{H}} 7.22\right)$ to C-4 $\left(\delta_{\mathrm{C}} 176.0\right)$ which was much stronger than that from $\mathrm{H}-8\left(\delta_{\mathrm{H}} 6.84\right)$ to C-4, indicating that $\delta_{\mathrm{H}} 7.22$ and $\delta_{\mathrm{H}} 6.84$ were assigned to $\mathrm{H}-5$ and H-8, respectively (Figure 2). Thus, the structure of 1 was assigned as 6,7-dihydroxy-2-(2-phenylethyl)chromone.

Table 1. ${ }^{1} \mathrm{H}-(500 \mathrm{MHz})$ and ${ }^{13} \mathrm{C}-(125 \mathrm{MHz})$ NMR spectral data of compounds $1-4$ ( $\delta$ in ppm, J in Hz).

\begin{tabular}{ccccccccc}
\hline \multirow{2}{*}{ No. } & \multicolumn{2}{c}{$\mathbf{1}^{\mathbf{a}}$} & \multicolumn{2}{c}{$\mathbf{2}^{\mathbf{a}}$} & $\mathbf{3}^{\mathbf{a}}$ & \multicolumn{2}{c}{$\mathbf{4}^{\mathbf{b}}$} \\
\cline { 2 - 9 } & $\boldsymbol{\delta}_{\mathbf{C}}$ & $\boldsymbol{\delta}_{\mathbf{H}}$ & $\boldsymbol{\delta}_{\mathbf{C}}$ & $\boldsymbol{\delta}_{\mathbf{H}}$ & $\boldsymbol{\delta}_{\mathbf{C}}$ & $\boldsymbol{\delta}_{\mathbf{H}}$ & $\boldsymbol{\delta}_{\mathbf{C}}$ & $\boldsymbol{\delta}_{\mathbf{H}}$ \\
\hline 2 & 167.2 & & 167.8 & & 170.8 & & 163.6 & \\
3 & 108.6 & $5.99 \mathrm{~s}$ & 108.9 & $6.03 \mathrm{~s}$ & 108.4 & $6.22 \mathrm{~s}$ & 108.4 & $6.22 \mathrm{~s}$ \\
4 & 176.0 & & 176.3 & & 183.1 & & 183.7 & \\
5 & 107.6 & $7.22 \mathrm{~s}$ & 107.3 & $7.23 \mathrm{~s}$ & 151.2 & & 161.5 & \\
6 & 144.3 & & 145.1 & & 109.8 & $6.61 \mathrm{~d}(8.2)$, overlap & 111.4 & $6.79 \mathrm{~d}(8.3)$ \\
\hline
\end{tabular}


Table 1. Cont.

\begin{tabular}{|c|c|c|c|c|c|c|c|c|}
\hline \multirow{2}{*}{ No. } & \multicolumn{2}{|c|}{$1^{a}$} & \multicolumn{2}{|c|}{$2^{a}$} & \multicolumn{2}{|r|}{$3^{a}$} & \multicolumn{2}{|c|}{$4^{b}$} \\
\hline & $\delta_{C}$ & $\delta_{H}$ & $\delta_{C}$ & $\delta_{H}$ & $\delta_{C}$ & $\delta_{H}$ & $\delta_{C}$ & $\delta_{H}$ \\
\hline 7 & 152.0 & & 153.6 & & 121.8 & $7.17 \mathrm{~d}(8.2)$ & 135.4 & 7.51 t (8.3) \\
\hline 8 & 102.8 & $6.84 \mathrm{~s}$ & 100.4 & $7.12 \mathrm{~s}$ & 137.6 & & 106.9 & $6.96 \mathrm{~d}(8.3)$ \\
\hline 9 & 151.0 & & 151.1 & & 144.5 & & 156.4 & \\
\hline 10 & 115.8 & & 116.6 & & 110.4 & & 111.1 & \\
\hline $1^{\prime}$ & 140.2 & & 132.1 & & 132.5 & & 127.7 & \\
\hline $2^{\prime}$ & 128.4 & $7.26 \mathrm{~m}$ & 129.4 & $7.15 \mathrm{~d}(8.5)$ & 115.7 & $6.67 \mathrm{~d}(2.2)$ & 129.6 & $7.54 \mathrm{~d}(8.1)$ \\
\hline $3^{\prime}$ & 128.3 & $7.26 \mathrm{~m}$ & 113.9 & $6.83 \mathrm{~d}(8.5)$ & 146.2 & & 114.7 & $6.95 \mathrm{~d}(8.1)$ \\
\hline $4^{\prime}$ & 126.2 & $7.19 \mathrm{~m}$ & 157.8 & & 146.4 & & 161.0 & \\
\hline $5^{\prime}$ & 128.3 & $7.26 \mathrm{~m}$ & 113.9 & $6.83 \mathrm{~d}(8.5)$ & 112.3 & $6.80 \mathrm{~d}(8.2)$ & 114.7 & $6.95 \mathrm{~d}(8.1)$ \\
\hline $6^{\prime}$ & 128.4 & $7.26 \mathrm{~m}$ & 129.4 & $7.15 \mathrm{~d}(8.5)$ & 118.8 & $6.61 \mathrm{~d}(2.2,8.2)$, overlap & 129.6 & $7.54 \mathrm{~d}(8.1)$ \\
\hline $7^{\prime}$ & 32.1 & $2.97 \mathrm{~m}$ & 31.4 & $2.90 \mathrm{~m}$ & 31.2 & $2.92 \mathrm{~m}$ & 137.9 & $7.59 \mathrm{~d}(16.0)$ \\
\hline $8^{\prime}$ & 34.7 & $2.90 \mathrm{~m}$ & 35.2 & $2.90 \mathrm{~m}$ & 35.2 & $2.92 \mathrm{~m}$ & 117.3 & $6.63 \mathrm{~d}(16.0)$ \\
\hline $5-\mathrm{OH}$ & & & & & & $11.85 \mathrm{~s}$ & & \\
\hline $6-\mathrm{OH}$ & & $9.70 \mathrm{~s}$ & & $9.72 \mathrm{~s}$ & & & & \\
\hline 7-OH & & $10.35 \mathrm{~s}$ & & & & & & \\
\hline $8-\mathrm{OH}$ & & & & & & $9.67 \mathrm{~s}$ & & \\
\hline $3^{\prime}-\mathrm{OH}$ & & & & & & $8.85 \mathrm{~s}$ & & \\
\hline $7-\mathrm{OCH}_{3}$ & & & 56.3 & $3.89 \mathrm{~s}$ & & & & \\
\hline $4^{\prime}-\mathrm{OCH}_{3}$ & & & 55.0 & $3.70 \mathrm{~s}$ & 55.6 & $3.71 \mathrm{~s}$ & 55.6 & $3.86 \mathrm{~s}$ \\
\hline
\end{tabular}
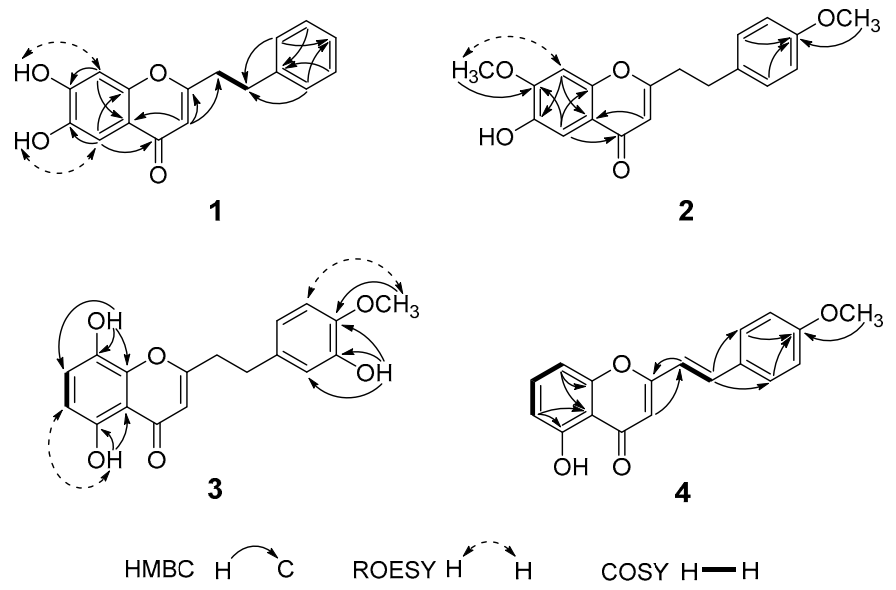

Figure 2. Key HMBC, ROESY, and ${ }^{1} \mathrm{H}^{-1} \mathrm{H}$ COSY correlations of compounds 1-4.

Compound 2 was obtained as a colorless oil. Its molecular formula was deduced to be $\mathrm{C}_{19} \mathrm{H}_{18} \mathrm{O}_{5}$ on the basis of HR-ESI-MS data $\left(\mathrm{m} / z\right.$ 327.1224 $\left.[\mathrm{M}+\mathrm{H}]^{+}\right)$. The ${ }^{1} \mathrm{H}-\mathrm{NMR}$ spectrum showed the presence of two methoxy groups at $\delta_{\mathrm{H}} 3.89\left(7-\mathrm{OCH}_{3}\right)$ and $\delta_{\mathrm{H}} 3.70\left(4^{\prime}-\mathrm{OCH}_{3}\right)$, one hydroxyl group at $\delta_{\mathrm{H}} 9.72$ (6-OH), one set of protons on the $\mathrm{AA}^{\prime} \mathrm{BB}^{\prime}$ coupling system at $\delta_{\mathrm{H}} 7.15\left(2 \mathrm{H}, \mathrm{d}, J=8.5 \mathrm{~Hz}, \mathrm{H}-2^{\prime}, 6^{\prime}\right)$ and $\delta_{\mathrm{H}} 6.83\left(2 \mathrm{H}, \mathrm{d}, J=8.5 \mathrm{~Hz}, \mathrm{H}-3^{\prime}, 5^{\prime}\right)$, as well as two singlet aromatic protons at $\delta_{\mathrm{H}} 7.23(1 \mathrm{H}, \mathrm{s}, \mathrm{H}-5)$ and $7.12(1 \mathrm{H}, \mathrm{s}, \mathrm{H}-8)$. The ${ }^{1} \mathrm{H}$ - and ${ }^{13} \mathrm{C}-\mathrm{NMR}$ data of 2 closely resembled that of known compound 6-hydroxy-7-methoxy-2-(2-phenylethyl)chromone [17], except for an additional methoxy group in 2. These also can be confirmed by the HMBC correlation of $\mathrm{OCH}_{3}\left(\delta_{\mathrm{H}} 3.89\right)$ to $\mathrm{C}-7$ ( $\left.\delta_{\mathrm{C}} 153.6\right)$, and its ROESY correlation with $\mathrm{H}-8\left(\delta_{\mathrm{H}} 7.12\right)$. The position of an additional methoxy group at $\mathrm{C}-4^{\prime}$ was determined by the HMBC correlations from $4^{\prime}-\mathrm{OCH}_{3}\left(\delta_{\mathrm{H}} 3.70\right), \mathrm{H}-2^{\prime} / \mathrm{H}-6^{\prime}\left(\delta_{\mathrm{H}} 7.15\right)$ and $\mathrm{H}-3^{\prime} / \mathrm{H}-5^{\prime}$ $\left(\delta_{\mathrm{H}} 6.83\right)$ to the same quaternary carbon $C-4^{\prime}\left(\delta_{\mathrm{C}} 157.8\right)$ (Figure 2$)$. Thus, the structure of 2 was proposed to be 6-hydroxy-7-methoxy-2-[2-(4-methoxyphenyl)ethyl]chromone.

Compound 3 was obtained as a yellow powder. Its molecular formula was deduced to be $\mathrm{C}_{18} \mathrm{H}_{16} \mathrm{O}_{6}$ on the basis of HR-ESI-MS $\left(\mathrm{m} / \mathrm{z} 327.0873[\mathrm{M}-\mathrm{H}]^{-}\right)$. The ${ }^{1} \mathrm{H}-\mathrm{NMR}$ spectrum showed the presence of a methoxy group at $\delta_{\mathrm{H}} 3.71\left(4^{\prime}-\mathrm{OCH}_{3}\right)$, three hydroxyl groups at $\delta_{\mathrm{H}}$ 
$9.67(8-\mathrm{OH}), 11.85(5-\mathrm{OH})$ and $8.85\left(3^{\prime}-\mathrm{OH}\right)$, one set of signals with two ortho-coupled doublets at $\delta_{\mathrm{H}} 6.61(1 \mathrm{H}, \mathrm{d}, J=8.2 \mathrm{~Hz}, \mathrm{H}-6)$ and $\delta_{\mathrm{H}} 7.17(1 \mathrm{H}, \mathrm{d}, J=8.2 \mathrm{~Hz}, \mathrm{H}-7)$, and another set of ABX coupling aromatic system signals at $\delta_{\mathrm{H}} 6.61\left(1 \mathrm{H}, \mathrm{dd}, J=8.2,2.2 \mathrm{~Hz}, \mathrm{H}-6^{\prime}\right), \delta_{\mathrm{H}} 6.67$ $\left(1 \mathrm{H}, \mathrm{d}, J=2.2 \mathrm{~Hz}, \mathrm{H}-2^{\prime}\right)$ and $\delta_{\mathrm{H}} 6.80\left(1 \mathrm{H}, \mathrm{d}, J=8.2 \mathrm{~Hz}, \mathrm{H}-5^{\prime}\right)$. The comparison of NMR data between 3 and 5,8-dihydroxy-2-[2-(4-methoxyphenyl)ethyl]chromone [18] suggested that their structures were closely related, except that an additional hydroxy group was located at C- $3^{\prime}$ in 3. HMBC correlations from the hydroxy group at $\delta_{\mathrm{H}} 8.85$ to $\mathrm{C}-4^{\prime}\left(\delta_{\mathrm{C}} 146.4\right), \mathrm{C}-3^{\prime}\left(\delta_{\mathrm{C}} 146.2\right)$ and $C-2^{\prime}\left(\delta_{C} 115.7\right)$ (Figure 2) further corroborated this deduction. Thus, 3 was deduced to be 5,8-dihydroxy-2-[2-(3-hydroxy-4-methoxyphenyl)ethyl]chromone.

Compound 4 was obtained as a yellow powder, and its molecular formula was deduced to be $\mathrm{C}_{18} \mathrm{H}_{16} \mathrm{O}_{4}$ on the basis of HR-ESI-MS $\left(\mathrm{m} / z 293.1787[\mathrm{M}-\mathrm{H}]^{-}\right)$. The IR spectrum indicated the presence of a hydroxyl $\left(3435 \mathrm{~cm}^{-1}\right)$ and an $\alpha, \beta$-unsaturated carbonyl $\left(1631 \mathrm{~cm}^{-1}\right)$ group. Its ${ }^{1} \mathrm{H}-\mathrm{NMR}$ spectroscopic data showed two trans-olefinic protons at $\delta_{\mathrm{H}} 7.59\left(1 \mathrm{H}, \mathrm{d}, J=16.0 \mathrm{~Hz}, \mathrm{H}-7^{\prime}\right)$ and $\delta_{\mathrm{H}} 6.63$ $\left(1 \mathrm{H}, \mathrm{d}, J=16.0 \mathrm{~Hz}, \mathrm{H}-8^{\prime}\right)$, a set of $\mathrm{AA}^{\prime} \mathrm{BB}^{\prime}$ coupling aromatic systems at $\delta_{\mathrm{H}} 7.54\left(2 \mathrm{H}, \mathrm{d}, J=8.1 \mathrm{~Hz}, \mathrm{H}-2^{\prime}\right.$, $\left.6^{\prime}\right)$ and $\delta_{\mathrm{H}} 6.95\left(2 \mathrm{H}, \mathrm{d}, J=8.1 \mathrm{~Hz}, \mathrm{H}-3^{\prime}, 5^{\prime}\right)$, three mutual coupled aromatic protons at $\delta_{\mathrm{H}} 6.79(1 \mathrm{H}, \mathrm{d}$, $J=8.3 \mathrm{~Hz}, \mathrm{H}-6), \delta_{\mathrm{H}} 7.51(1 \mathrm{H}, \mathrm{t}, J=8.3 \mathrm{~Hz}, \mathrm{H}-7)$ and $\delta_{\mathrm{H}} 6.96(1 \mathrm{H}, \mathrm{d}, J=8.3 \mathrm{~Hz}, \mathrm{H}-8)$ corresponding to a 1,2,3-substituted phenyl moiety in the chromone nucleus, and a methoxy group at $\delta_{\mathrm{H}} 3.86(3 \mathrm{H}$, $\left.\mathrm{s}, \mathrm{OCH}_{3}-4^{\prime}\right)$. The ${ }^{1} \mathrm{H}$ - and ${ }^{13} \mathrm{C}-\mathrm{NMR}$ spectroscopic data of 4 showed a high degree of similarity with those of 5-hydroxy-2-(2-phenyletheyl)chromone [19]. The main difference observed was that signals for the trans double-bond $\left(\delta_{\mathrm{H}} 7.59\right.$ and $\left.\delta_{\mathrm{H}} 6.63\right)$ in 4 replaced the corresponding signals for two vicinal methylenes in 5-hydroxy-2-(2-phenyletheyl)chromone, and the presence of one methoxy signal in 4 . Finally, compound 4 was established to be 5-hydroxy-2-[2-(4-methoxyphenyl)ethenyl]chromone by a comprehensive analysis of its 2D-NMR data (Figure 2).

The structures of compounds 5-6, which have been isolated from agarwood, were identified as 6,7-dihydroxy-2-chromone (5) [16] and 6-hydroxy-2-[2-(4-hydroxyphenyl)ethyl]chromone (6) [17], respectively, by comparison of the-NMR and MS data with those reported by literature.

All isolated compounds were evaluated for their cytotoxic activity toward K562, BEL-7402, and SGC-7901 human cancer cell lines using the MTT assay, with paclitaxel as a positive control. For K562 and BEL-7402 cell lines, compound 5 showed relatively pronounced cytotoxicity with $\mathrm{IC}_{50}$ values of 8.36 and $5.76 \mu \mathrm{M}$. However, demethoxylation on $\mathrm{C}-4^{\prime}$ in compound 1 caused a significant decrease in the activity against the above cell lines with $\mathrm{IC}_{50}$ values of 18.1 and $20.1 \mu \mathrm{M}$, respectively. Both compounds $\mathbf{1}$ and $\mathbf{5}$ were inactive against the SGC-7901 cell line. Notably, compound 2, with a methoxyl substituted at C-7 instead of a hydroxyl as in compound 5, was active to all three cell lines, including moderate cytotoxicity against SGC-7901 and K562 cells with $\mathrm{IC}_{50}$ values of 17.8 and $13.9 \mu \mathrm{M}$, respectively, and weak cytotoxicity against BEL-7402 cells with an $\mathrm{IC}_{50}$ value of $31.9 \mu \mathrm{M}$. Compared with compound 5, compound 6 harbored a hydroxyl linked at $C-4^{\prime}$ and no substituent at C-7, and only showed weak cytotoxicity against $\mathrm{K} 562$ cells with an $\mathrm{IC}_{50}$ value of $47.0 \mu \mathrm{M}$. Compounds 3 and 4 were inactive against the aforementioned cell lines.

According to the results, we found that compounds 1, 2, 5 and $\mathbf{6}$ showed more effective cytotoxic activity to K-562 cells than to BEL-7402 and SGC-7901 cell lines. In addition, a comprehensive comparison of the cytotoxic activity of compounds 1-6 suggested that hydroxyls substituted at C-6 and C-7, respectively, as in $\mathbf{1}$ and $\mathbf{5}$, led to more potent activity, while $\mathbf{5}$ with methoxy at C-4' showed increased activity. Furthermore, the hydroxy group at C-6 was crucial for the cytotoxic activities among this type of compound.

\section{Experimental Section}

\subsection{General Information}

UV spectra were recorded on a Shimadzu UV-2550 spectrometer (Beckman, Brea, CA, USA). IR absorptions were obtained on a Nicolet 380 FT-IR instrument (Thermo, Pittsburgh, PA, USA) using 
KBr pellets. The-NMR spectra were recorded on Bruker Avance 500-NMR spectrometers (Bruker, Bremen, Germany), using TMS as an internal standard. HR-ESI-MS were measured with an API QSTAR Pulsar mass spectrometer (Bruker, Bremen, Germany) or Waters Autospec Premier (Waters, Milford, MA, USA). Column chromatography was performed with silica gel (60-80, 200-300 mesh, Qingdao Haiyang Chemical Co., Ltd, Qingdao, China), ODS gel (20-45 $\mu \mathrm{m}$, Fuji Silysia Chemi-cal Co., Ltd, Research Triangle Park, NC, USA), and Sephadex LH-20 (Merck, Darmstadt, Germany). TLC was carried out on silica gel GF254 (Qingdao Haiyang Chemical Co., Ltd, Qingdao, China), and spots were detected by spraying with $5 \% \mathrm{H}_{2} \mathrm{SO}_{4}$ in $\mathrm{EtOH}$ followed by heating.

\subsection{Plant Material}

The plant material was collected in Papua New Guinea, then traded in Macao, China's special administrative regions, in December 2014, and identified as agarwood originating from Gyrinops salicifolia by Prof. Dr. Hao-Fu Dai and Dr. Jun Wang (Institute of Tropical Bioscience and Biotechnology, Chinese Academy of Tropical Agricultural Sciences \& Hainan engineering research center of agarwood). A voucher specimen (CX 20141222) has been deposited at the Institute of Tropical Bioscience and Biotechnology, Chinese Academy of Tropical Agricultural Sciences.

\subsection{Extraction and Isolation}

The material of agarwood (491.1 g, dry weight) was extracted with $95 \% \mathrm{EtOH}(2 \mathrm{~L} \times 3)$ for three times at heating reflux and filtered. Then the $\mathrm{EtOH}$ was removed under vacuum, and get crude extract $177.4 \mathrm{~g}$. After that scatter it completely in $\mathrm{H}_{2} \mathrm{O}(2 \mathrm{~L})$, subsequently extracted with EtOAc $(2 \mathrm{~L} \times 3)$ followed by $n$-BuOH $(2 \mathrm{~L} \times 3)$. The EtOAc extract $(141.2 \mathrm{~g})$ was subjected to vacuum liquid chromatography with silica gel using a step gradient of $\mathrm{CHCl}_{3} / \mathrm{MeOH}(v / v, 1: 0,50: 1,25: 1,15: 1,10: 1$, 5:1, 2:1, 1:1, 0:1, $6 \mathrm{~L}$ of each) to yield 10 fractions (Fr.1-Fr.10). Fr.3 (7.2 g) was applied to ODS column chromatography with $\mathrm{MeOH} / \mathrm{H}_{2} \mathrm{O}(v / v, 3: 7,2: 3,1: 1,3: 2,7: 3,4: 1,9: 1,1: 0,2 \mathrm{~L}$ of each) divided to 19 fractions (Fr.3-1-Fr.3-19). Fr.3-3 (85.2 mg) was submitted to Sephadex LH-20 in MeOH to get Fr.3-3-1 (36.0 mg), then purified through silica gel column chromatography with $\mathrm{CHCl}_{3} / \mathrm{MeOH}(v / v, 100: 1)$ to obtain compound 6 (4.3 mg). Fr.3-5 (143.4 mg) was applied to Sephadex LH-20 in MeOH to get Fr.3-5-1 $(75.0 \mathrm{mg})$, then separated through silica gel column chromatography with $\mathrm{CHCl}_{3} / \mathrm{MeOH}(v / v, 100: 1)$ to afford compound $1(5.1 \mathrm{mg})$. Fr.3-6 $(99.3 \mathrm{mg})$ was applied to Sephadex LH-20 in MeOH to get Fr.3-6-1 $(66.0 \mathrm{mg})$, then compound $5(18.0 \mathrm{mg})$ was obtained through silica gel column chromatography with $\mathrm{CHCl}_{3}-\mathrm{MeOH}(v / v, 100: 1)$. Fr.3-10 (156.1 mg) was applied to Sephadex LH-20 (MeOH; $\mathrm{CHCl}_{3} / \mathrm{MeOH}$, $v / v, 1: 1)$ to get Fr.3-10-1 (63.0 mg), then purified through silica gel column chromatography (petroleum ether/EtOAc, $v / v, 40: 1)$ to obtain compound $4(2.0 \mathrm{mg})$. Fr.3-12 (62.6 mg) was applied to Sephadex $\mathrm{LH}-20(\mathrm{MeOH})$, then purified through silica gel column chromatography $\left(\mathrm{CHCl}_{3} / \mathrm{MeOH}, v / v, 150: 1\right)$ to obtain compound $3(6.7 \mathrm{mg})$. Fr.3-14 (108.0 mg) was applied to Sephadex LH-20 $(\mathrm{MeOH})$, then purified through silica gel column chromatography $\left(\mathrm{CHCl}_{3} / \mathrm{MeOH}, v / v, 500: 1\right)$ to obtain compound 2 (14.0 mg).

6,7-Dihydroxy-2-(2-phenylethyl)chromone (1): jacinth powder; UV (MeOH) $\lambda_{\max }(\log \varepsilon)$ : 208 (4.69), 228 (4.58), 282 (4.22), 298 (4.08), $322(4.25) \mathrm{nm}$; IR (KBr) $v_{\max } 3434,1632,1384,697 \mathrm{~cm}^{-1} ;{ }^{1} \mathrm{H}-(500 \mathrm{MHz})$ and ${ }^{13} \mathrm{C}-(125 \mathrm{MHz}) \mathrm{NMR}$ spectral data see Table 1; HR-ESI-MS: $\mathrm{m} / z 281.0820[\mathrm{M}-\mathrm{H}]^{-}$(calcd for $\left.\mathrm{C}_{17} \mathrm{H}_{14} \mathrm{O}_{4}, 282.0892\right)$.

6-Hydroxy-7-methoxy-2-[2-(4-methoxyphenyl)ethyl]chromone (2): colorless oil; UV (MeOH) $\lambda_{\max }(\log \varepsilon$ ): 230 (4.78), 280 (4.41), 298 (4.24), 322 (4.39) nm; IR (KBr) $v_{\max } 3404,1639,1385,1017 \mathrm{~cm}^{-1} ;{ }^{1} \mathrm{H}-(500 \mathrm{MHz})$ and ${ }^{13} \mathrm{C}-(125 \mathrm{MHz}) \mathrm{NMR}$ spectral data see Table 1; HR-ESI-MS: $m / z 327.1224[\mathrm{M}+\mathrm{H}]^{+}$(calcd for $\left.\mathrm{C}_{19} \mathrm{H}_{18} \mathrm{O}_{5}, 326.1154\right)$. 
5,8-Dihydroxy-2-[2-(3-hydroxy-4-methoxyphenyl)ethyl]chromone (3): yellow powder; UV (MeOH) $\lambda_{\max }$ (log ع): 204 (5.12), 224 (4.68), 256 (4.55), 296 (4.65), 320 (4.05) nm; IR (KBr) $v_{\max }$ 3467, 1634, 1015, $670 \mathrm{~cm}^{-1} ;{ }^{1} \mathrm{H}-(500 \mathrm{MHz})$ and ${ }^{13} \mathrm{C}-(125 \mathrm{MHz})$ NMR spectral data see Table 1 ; HR-ESI-MS: $\mathrm{m} / \mathrm{z} 327.0873$ $[\mathrm{M}-\mathrm{H}]^{-}$(calcd for $\left.\mathrm{C}_{18} \mathrm{H}_{16} \mathrm{O}_{6}, 328.0947\right)$.

5-Hydroxy-2-[2-(4-methoxyphenyl)ethenyl]chromone (4): yellow powder; $\mathrm{UV}(\mathrm{MeOH}) \lambda_{\max }(\log \varepsilon)$ : 204 (5.04), 224 (4.56), 256 (4.15), 296 (3.92), 306 (3.73) nm; IR (KBr) $v_{\max }$ 3435, 1631, 1384, $772 \mathrm{~cm}^{-1}$; ${ }^{1} \mathrm{H}-(500 \mathrm{MHz})$ and ${ }^{13} \mathrm{C}-(125 \mathrm{MHz}) \mathrm{NMR}$ spectral data see Table 1 ; HR-ESI-MS: $\mathrm{m} / z 293.1787[\mathrm{M}-\mathrm{H}]^{-}$ (calcd for $\mathrm{C}_{18} \mathrm{H}_{16} \mathrm{O}_{4}, 294.1858$ ).

\subsection{Bioassay of Cytotoxic Activity}

Human cancer cell lines, gastric carcinoma (SGC-7901), myeloid leukemia (K562), and hepatocellular carcinoma (BEL-7402), were obtained from the Cell Bank of Type Culture Collection of the Chinese Academy of Sciences, Shanghai Institute of Cell Biology. MTT assay [20,21] was used to determine the growth inhibition of the tested cell lines. Cells were cultured in RPMI 1640 medium supplemented with $10 \%$ fetal bovine serum, $100 \mathrm{IU} / \mathrm{mL}$ penicillin, and $100 \mathrm{mg} / \mathrm{mL}$ streptomycin at $37^{\circ} \mathrm{C}$ and $5 \%$ $\mathrm{CO}_{2}$ with $90 \%$ humidity. The logarithmic phase cells $(90 \mu \mathrm{L})$ were seeded onto 96 -well plates at the concentration of $5 \times 10^{4} \mathrm{cell} / \mathrm{mL}$. The following specific experimental procedures were the same as those described previously [22]. The results of the cytotoxic activity experiment are shown in Table 2.

Table 2. Cytotoxic activity of 1-6 against human tumor cell lines.

\begin{tabular}{cccc}
\hline \multirow{2}{*}{ Compound } & \multicolumn{3}{c}{ IC $_{\mathbf{5 0}}(\boldsymbol{\mu M})$} \\
\cline { 2 - 4 } & SGC-7901 & K-562 & BEL-7402 \\
\hline $\mathbf{1}$ & $>50$ & 18.1 & 20.1 \\
$\mathbf{2}$ & 17.8 & 13.9 & 31.9 \\
$\mathbf{3}$ & $>50$ & $>50$ & $>50$ \\
$\mathbf{4}$ & $>50$ & $>50$ & $>50$ \\
$\mathbf{5}$ & $>50$ & 8.36 & 5.76 \\
$\mathbf{6}$ & $>50$ & 47.0 & $>50$ \\
Paclitaxel $^{\mathrm{b}}$ & 1.80 & 7.20 & 2.40 \\
\hline \multicolumn{5}{c}{ b positive control. }
\end{tabular}

\section{Conclusions}

To the best of our knowledge, 2-(2-phenylethyl)chromone derivatives, the compounds with a chromone skeleton, such as 1-3, 5 and $\mathbf{6}$ isolated from the agarwood of Gyrinops salicifolia, are very common in nature, and have been reported in agarwoods from Aquilaria species $[5,16]$. For 2-(2-phenylethenyl)chromone derivatives, only one compound, 6-hydroxy-2-[2-(4-hydroxy-3methoxyphenyl)ethenyl]chromone [16], was found in agarwood from Aquilaria sinensis. Interestingly, compound 4, discovered during this study, was the second 2-(2-phenylethenyl)chromone derivative from agarwood. Furthermore, eight known 2-(2-phenylethyl)chromone derivatives and a series of sesquiterpenes have been isolated from the agarwood of Gyrinops salicifolia in our previous study [23,24], and most of them have also been reported in agarwoods from Aquilaria sp. [5,6,16]. As we can see, the main chemical constituents of agarwood from Gyrinops salicifolia are similar to the agarwood resins from Aquilaria sp., so it can be considered that Gyrinops salicifolia is one of the commercial agarwood-producing species.

Supplementary Materials: The following are available online at http://www.mdpi.com/1420-3049/21/10/1313/ s1. The HR-ESI-MS,-NMR (1D and 2D) of compounds $\mathbf{1 - 4}$ are available as supporting information. 
Acknowledgments: This work was financially supported by Fundamental Research Funds for Special Funds for Agro-scientific Research in the Public Interest (201303117), the Major Technology Project of Hainan Province (ZDKJ2016004-03), and the National Nonprofit Institute Research Grant of CATAS-ITBB (ITBB2015RC03, ITBB2015ZD02).

Author Contributions: The list authors contributed to this work as follows: H. Shao performed the isolation, structure elucidation of the constituents, and prepared the manuscript. W.H. Dong collected the plant material. W.L. Mei and W. Li contributed to the revision of this manuscript. C.J. Gai conducted the bioassay experiments. The whole research was performed based on the planning of H.F. Dai and G.P. Zhu. All authors approved the final version of the manuscript.

Conflicts of Interest: The authors declare no competing financial interest.

\section{References}

1. Borris, R.P.; Blaskó, G.; Cordell, G.A. Ethnopharmacologic and phytochemical studies of the Thymelaeaceae. J. Ethnopharmacol. 1988, 24, 41-91. [CrossRef]

2. Compton, J.; Ishihara, A. The Use and Trade of Agarwood in Japan. A TRAFFIC report to the CITES Secretariat. Available online: https://cites.org/sites/default/files/common/com/pc/15/X-PC15-06-Inf. pdf (accessed on 1 September 2016).

3. Persoon, G.A.; Van Beek, H.H. Growing 'the wood of the gods': Agarwood production in Southeast Asia. In Smallholder Tree Growing for Rural Development and Environmental Services; Springer: Dordrecht, The Netherlands, 2008; Volume 5, pp. 245-262.

4. China Pharmacopoeia Editorial Board. Pharmacopoeia of the People's Republic of China, (Part 1); China Medical Science and Technology Press: Beijing, China, 2010; p. 172.

5. Naef, R. The volatile and semi-volatile constituents of agarwood, the infected heartwood of Aquilaria species: A review. Flavour. Frag. J. 2011, 26, 73-87. [CrossRef]

6. Chen, H.Q.; Wei, J.H.; Yang, J.S.; Zhang, Z.; Yang, Y.; Gao, Z.H.; Sui, C.; Gong, B. Chemical constituents of agarwood originating from the endemic genus Aquilaria plants. Chem. Biodivers. 2012, 9, 236-250. [CrossRef] [PubMed]

7. Kenmotsu, Y.; Ogita, S.; Katoh, Y.; Yamamura, Y.; Takao, Y.; Tatsuo, Y.; Kurosaki, F. Methyl jasmonate-induced enhancement of expression activity of Am-FaPS-1, a putative farnesyl diphosphate synthase gene from Aquilaria microcarpa. J. Nat. Med. 2011, 65, 194-197. [CrossRef] [PubMed]

8. Kumeta, Y.; Ito, M. Characterization of $\delta$-guaiene synthases from cultured cells of Aquilaria, responsible for the formation of the sesquiterpenes in agarwood. Plant. Physiol. 2010, 154, 1998-2007. [CrossRef] [PubMed]

9. Gao, Z.H.; Wei, J.H.; Yang, Y.; Zhang, Z.; Zhao, W.T. Selection and validation of reference genes for studying stress-related agarwood formation of Aquilaria sinensis. Plant. Cell. Rep. 2012, 31, 1759-1768. [CrossRef] [PubMed]

10. Lee, S.Y.; Mohamed, R. The origin and domestication of Aquilaria, an important agarwood-producing genus. In Agarwood; Springer Singapore: Singapore, 2016; pp. 1-20.

11. Mulyaningsih, T.; Yamada, I. Notes on some species of agarwood in Nusa Tenggara, Celebes and West Papua. In Natural Resource Management and Socio-Economic Transformation under the Decentralization in Indonesia: Toward Sulawesi Area Studies; CSEAS Kyoto University: Kyoto, Japan, 2008; pp. 365-372.

12. Schun, Y.; Cordell, G.A.; Cox, P.J.; Howie, R.A. Wallenone, $\mathrm{a}_{32}$ triterpenoid from the leaves of Gyrinops walla. Phytochemistry 1986, 25, 753-755. [CrossRef]

13. Subasinghe, S.M.C.U.P.; Hettiarachchi, D.S. Characterisation of agarwood type resin of Gyrinops walla Gaertn growing in selected populations in Sri Lanka. Ind. Crop. Prod. 2015, 69, 76-79. [CrossRef]

14. Yang, D.L.; Mei, W.L.; Zeng, Y.B.; Guo, Z.K.; Zhao, Y.X.; Wang, H.; Zuo, W.J.; Dong, W.H.; Wang, Q.H.; Dai, H.F. 2-(2-phenylethyl)chromone derivatives in Chinese Agarwood “Qi-Nan” from Aquilaria sinensis. Planta. Med. 2013, 79, 1329-1334. [PubMed]

15. Li, W.; Cai, C.H.; Guo, Z.K.; Wang, H.; Zuo, W.J.; Dong, W.H.; Mei, W.L.; Dai, H.F. Five new eudesmane-type sesquiterpenoids from Chinese agarwood induced by artificial holing. Fitoterapia 2015, 100, 44-49. [CrossRef] [PubMed]

16. Yang, L.; Qiao, L.R.; Xie, D.; Yuan, Y.H.; Chen, N.H.; Dai, J.G.; Guo, S.X. 2-(2-Phenylethyl)chromones from Chinese eaglewood. Phytochemistry 2012, 76, 92-97. [CrossRef] [PubMed] 
17. Konishi, T.; Konoshima, T.; Shimada, Y.; Kiyosawa, S. Six new 2-(2-phenylethyl)chromones from Agarwood. Chem. Pharm. Bull. 2002, 50, 419-422. [CrossRef] [PubMed]

18. Yang, J.S.; Wang, Y.L.; Su, Y.L. Studies on the chemical constituents of Aquilaria sinensis (Lour.) Gilg. V. Isolation and characterization of three 2-(2-phenylethyl)chromone derivatives. Acta Pharmaceutica Sinica 1989, 25, 186-190.

19. Yoon, J.S.; Lee, M.K.; Sung, S.H.; Kim, Y.C. Neuroprotective 2-(2-Phenylethyl) chromones of Imperata cylindrical. J. Nat. Prod. 2006, 69, 290-291. [CrossRef] [PubMed]

20. Mosmann, T. Rapid colorimetric assay for cellular growth and survival: Application to proliferation and cytotoxicity assays. J. Immunol. Methods. 1983, 65, 55-63. [CrossRef]

21. Ferrari, M.; Fornasiero, M.C.; Isetta, A.M. MTT colorimetric assay for testing macrophage cytotoxic activity in vitro. J. Immunol. Methods 1990, 131, 165-172. [CrossRef]

22. Liu, S.; Liu, S.B.; Zuo, W.J.; Guo, Z.K.; Mei, W.L.; Dai, H.F. New sesquiterpenoids from Aglaiaodorata var. microphyllina and their cytotoxic activity. Fitoterapia 2014, 92, 93-99. [PubMed]

23. Shao, H.; Mei, W.L.; Li, W.; Gai, C.J.; Zhu, G.P.; Dai, H.F. Chemical constituents of agarwood originating from Gyrinops salicifolia. Nat. Prod. Res. Dev. 2015, 27, 2046-2049.

24. Shao, H.; Mei, W.L.; Kong, F.D.; Dong, W.H.; Gai, C.J.; Li, W.; Dai, H.F. Sesquiterpenes of agarwood from Gyrinops salicifolia. Fitoterapia 2016, 113, 182-187. [CrossRef] [PubMed]

Sample Availability: Samples of the compounds are not available from the authors.

(C) 2016 by the authors; licensee MDPI, Basel, Switzerland. This article is an open access article distributed under the terms and conditions of the Creative Commons Attribution (CC-BY) license (http://creativecommons.org/licenses/by/4.0/). 